\title{
ПРО СПІВПРАЦЮ ІНСТИТУТУ ОБДАРОВАНОЇ ДИТИНИ НАПН УКРАЇНИ І МАЛОЇ АКАДЕМІЇ НАУК УКРАЇНИ ЩОДО ЗАПРОВАДЖЕННЯ СПЕЦІАЛІЗОВАНОЇ ОСВІТИ НАУКОВОГО СПРЯМУВАННЯ
}

\author{
Наукова доповідь на засіданні Президії НАПН України 19 березня 2020 р.
} https://doi.org/10.37472/2707-305X-2020-2-1-2-4

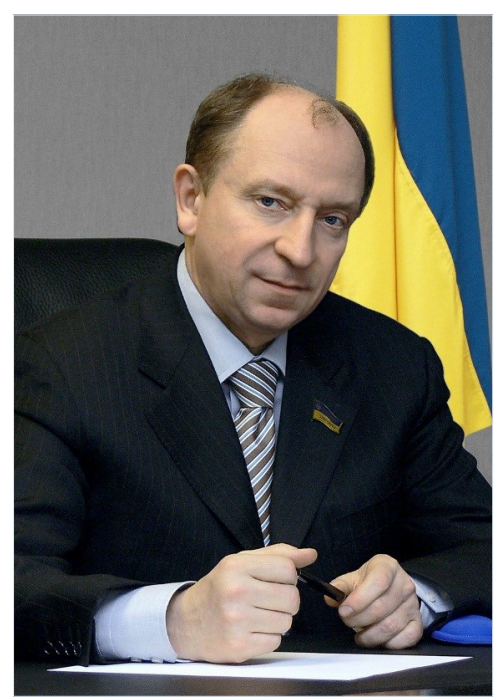

\begin{abstract}
ДОВГИЙ Станіслав Олексійович доктор фрізико-математичних наук, професор, дійсний член (академік) НАН України і НАПН України, президент Національного чентру «Мала академія наук України», м. Київ, Україна

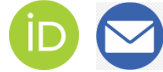

ГАЛЬЧЕНКО Максим Сергійович кандидат філософських наук, директор Інституту обдарованої дитини Національної академії педагогічних наук України, м. Київ, Україна

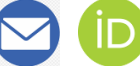

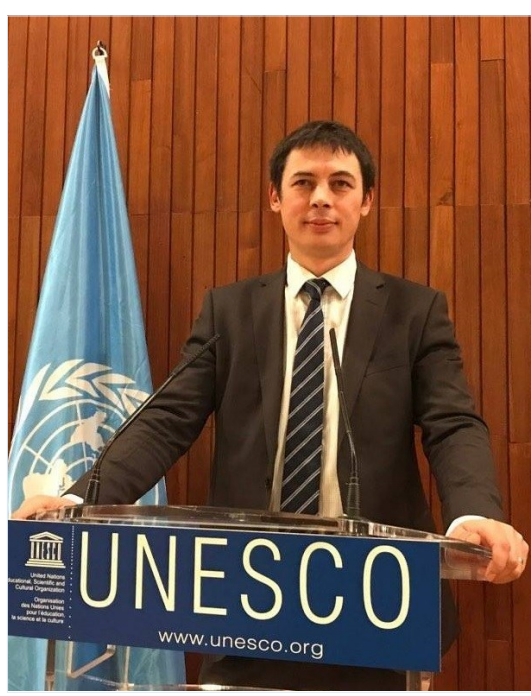

Анотація. У доповіді розкрито основні напрями співпраці Інституту обдарованої дитини НАПН України та Малої академії наук України із запровадження спеціалізованої освіти наукового спрямування. Акцентується, що Закон України «Про освіту» створює легітимне підгрунтя для переорієнтації освітнього прочесу з механічного заучування формального набору знання до розвитку дослідницьких компетенцій як універсальних особистісних пізнавально-креативних інструментів. Центральною тезою доповіді є судження, що ефрективна імплементація норм Закону України із запровадження спеціалізованої освіти наукового спрямування у широку освітню практику неможлива без синергії основних стейкхолдерів освітнього процесу, які предметно займаються иією проблематикою, а саме: Інституту обдарованої дитини НАПн України та Малої академії наук України. Сьогодні синергія зусиль Інституту обдарованої дитини НАПн України та Малої академії наук України простежується на кількох рівнях: нормативне, науково-організаційне та науковометодичне забезпечення освіти наукового спрямування і міннародне наукове співробітництво. Попри значні здобутки у сфері запровадження спеціалізованої освіти наукового спрямування в умовах реалізації концепції Нової української школи наголошується на низці необхідних кроків у найближчий перспективі, що сприятимуть як популяризації наукової освіти на вітчизняних теренах, так і підвищенню ефективності самого освітнього процесу в системі освіти України.

Ключові слова: спеціалізована освіта наукового спрямування; обдарованість; дослідницькі компетенціі; Інститут обдарованої дитини НАПН України; Мала академія наук України.

У Законі України «Про освіту» спеціалізована освіта наукового спрямування проголошується як відповідь на суспільний запит щодо пошуку і розвитку інтелектуально обдарованих дітей, підготовки їх до діяльності в умовах прогресу інноваційного типу, до життя у суспільстві знань. Стрижнем ідеології цього підходу $\epsilon$ ідея переорієнтації освітнього процесу в закладах освіти з механічного заучування учнями певної кількості формального знання, визначеного навчальними програмами і стандартами, на розвиток у них дослідницьких компетентностей, що стануть універсальними пізнавальнокреативними інструментами. Це дає можливість гнучко реагувати на актуальні виклики багатьох життєвих суспільних та індивідуальних ситуацій, 
обґрунтовано передбачати їх розгортання і трансформацію у близькій та віддаленій перспективах. До структури компетентностей такого типу належить низка якісно специфічних здатностей особистості, з-поміж яких варто назвати: здатність до оперативної орієнтаційно-пошукової діяльності під час напрацювання інформаційного базису, необхідного для розв'язання проблеми; здатність особистості до переосмислення отриманої інформації за алгоритмами принципу когнітивної складності; готовність до побудови та розгортання на основі практичної діяльності, продукування інноваційних ідей та їх перевірки за допомогою методів і засобів наукового дослідження; здатність до розроблення альтернативних моделей системного розвязання проблем і вирішення часткових завдань тощо. Все це зумовлює необхідність упроваджувати та використовувати в освітньому процесі особливі педагогічні технології, що базуються на властивих науці способах пізнання і верифікації здобутої інформації. Особливо це стосується освіти обдарованих дітей, схильних до дослідницької діяльності.

3 огляду на зазначене зрозуміло, чому одним із провідних напрямів наукової діяльності Інституту обдарованої дитини НАПН України (далі Інститут) останніх років є дослідження науковометодичних засад розроблення і впровадження технологій спеціалізованої освіти наукового спрямування. 32019 р. в Інституті виконують два прикладні наукові дослідження: «Дидактичні засади навчання інтелектуально обдарованих учнів ліцею» і «Теоретико-методичні засади інтеграції формальної і неформальної освіти обдарованих учнів на основі освітніх програм спеціалізованої освіти наукового спрямування», які безпосередньо спрямовані на розв'язання проблем науково-методичного забезпечення наукової освіти. Згідно з ними передбачено: виокремлення засад конструювання змісту та реалізації середньої спеціалізованої освіти наукового спрямування; обґрунтування вимог до дидактичного забезпечення реалізації спеціалізованого блоку навчального плану наукових ліцеїв; обґрунтування форм організації освітнього процесу в наукових ліцеях; визначення теоретико-методичних засад побудови і реалізації освітніх програм спеціалізованої освіти наукового спрямування для обдарованих учнів гімназій і ліцеїв в умовах інтеграції формальної та неформальної освіти; розроблення навчальних програм

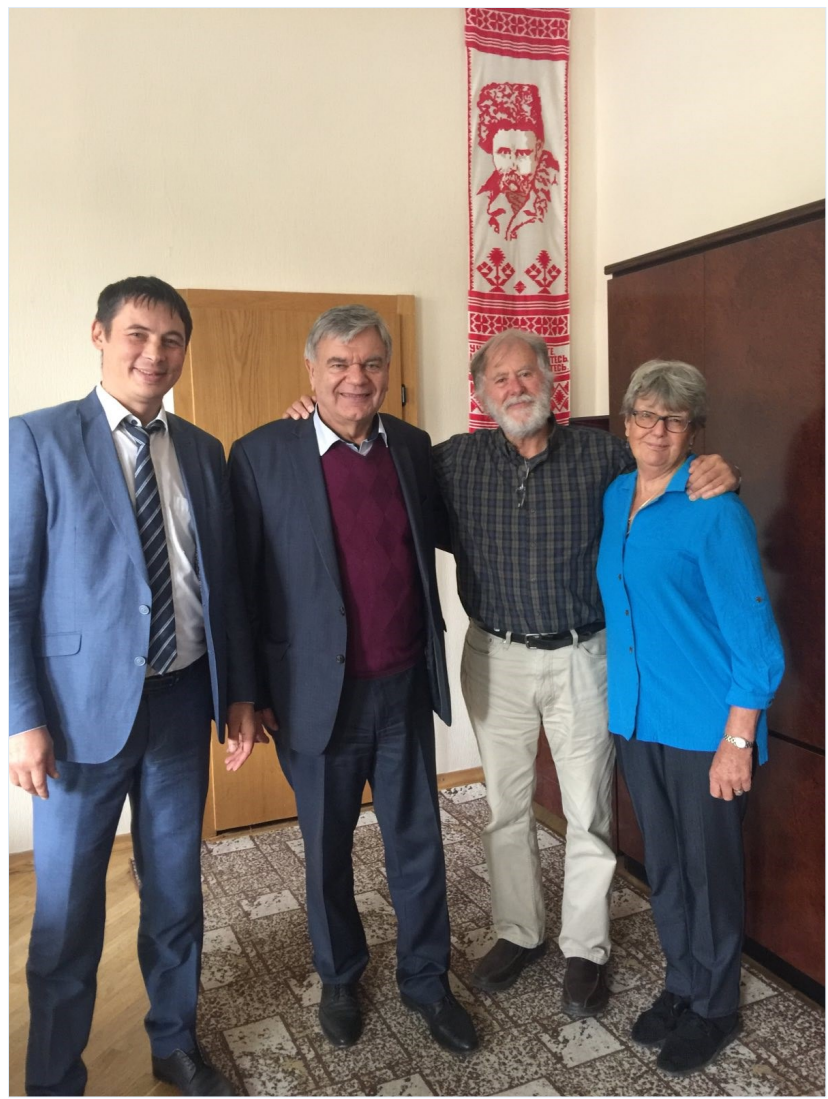

для обдарованих учнів гімназій і ліцеїв та запровадження їх в освітянську практику.

у 2020 р. розпочато також прикладне дослідження «Методичні засади інноваційних практик наукової освіти у регіональній мережі Центру ЮНЕСКО «Мала академія наук України» для розроблення концептуальних положень спеціалізованої освіти наукового спрямування на базі Малої академії наук України та підготовки відповідного методичного забезпечення.

Для виконання поставлених у дослідженнях завдань учені Інституту взяли участь у розробленні Стандарту спеціалізованої освіти наукового спрямування, який затверджено наказом МОH України від 16 жовтня 2019 р. № 103. Цей документ визначає: зміст спеціалізованої освіти наукового спрямування, що здобувається на рівнях базової та профільної середньої освіти; загальний обсяг навчального навантаження здобувачів освіти закладів спеціалізованої освіти наукового профілю; додаткові, окрім визначених стандартами загальної середньої освіти, вимоги до компетентностей учнів і результатів їхнього дослідно-орієнтованого навчання.

3 метою реалізації необхідних умов здобуття спеціалізованої освіти наукового спрямування відповідно до державного стандарту Інститут 


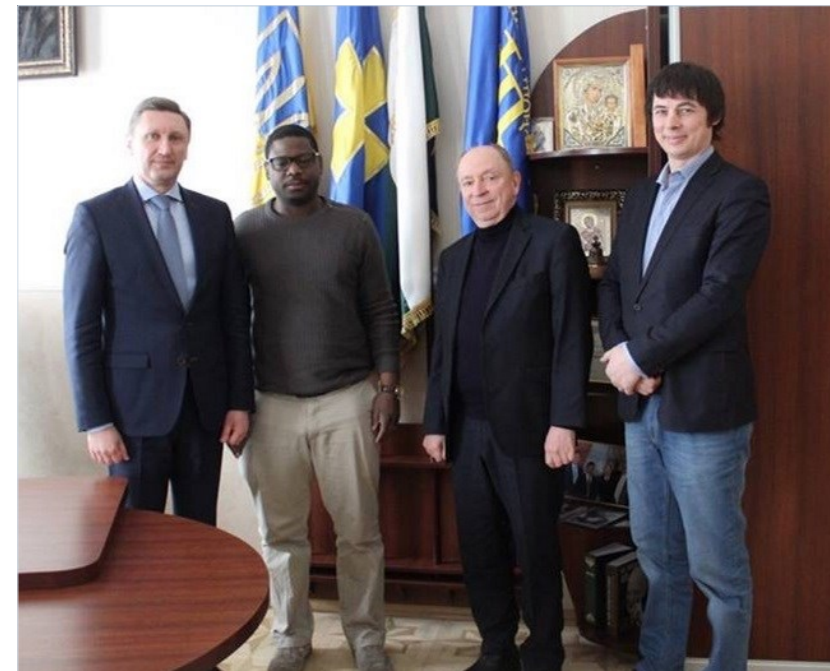

подав пропозиції до проєкту Положення про науковий ліцей і науковий ліцей-інтернат, передбаченого Планом заходів із запровадження Концепції реалізації державної політики у сфері реформування загальної середньої освіти «Нова українська школа».

Для забезпечення ефективності науководослідних робіт за цією проблематикою Інститут співпрацює з Малою академією наук України (далі - МАН), яка відповідно до своєї місії і статутних завдань забезпечує організацію та координацію науково-дослідницької діяльності учнів, створює умови для їхнього інтелектуального, духовного, творчого розвитку та професійного самовизначення, сприяє нарощуванню наукового потенціалу країни. Відповідно до укладеної угоди ця співпраця здійснюється за науковоорганізаційним та науково-методичним напрямами, а також передбачає міжнародну діяльність і виконання спільних проєктів.

За науково-організаційним напрямом роботи Інститут і МАН упродовж 2019 р. підготували та реалізували програму науково-практичних семінарів для вчителів закладів загальної середньої та позашкільної освіти, а саме: «Розроблення спеціальних освітніх програм для обдарованих дітей, схильних до дослідницької діяльності»; «Дослідницький STEM-проєкт: планування, організація, реалізація». Ці заходи проведено на базі лабораторії експериментальних досліджень МАНЛаб. Слухачам запропонували ознайомитися 3 теоретичними положеннями щодо видів і можливостей дослідницьких STEM-проєктів. Проведено практичні заняття з підготовки та реалізації STEM-проєкту. Представлено міжнародний досвід створення та реалізації спеціальних освітніх програм для обдарованих дітей в умовах інтеграції формальної та неформальної освіти.
Розкрито визначальні підходи до розроблення спеціальних освітніх програм для обдарованих дітей. Запропоновано приклади спеціальних освітніх програм для обдарованих дітей, схильних до дослідницької діяльності.

Співробітники Інституту проводили також науково-практичні заняття для спеціалістів МАН під час III етапу Всеукраїнського конкурсу-захисту науково-дослідницьких робіт учнів-членів МАН 3 особливостей формування дослідницьких навичок учнів.

Проєкт «Відкрита освітня лабораторія» реалізується у МАН для задоволення потреб учнів у творчій самореалізації та професійному самовизначенні, а також для удосконалення професійної компетентності педагогів у сфері організації дослідницько-експериментальної діяльності учнів. У рамках проєкту співробітники Інституту провели заняття для учнів щодо організації науково-дослідницької діяльності, а також методико-консультаційні заняття для керівників, методистів наукових відділень і наукових товариств МАН, учителів закладів загальної середньої освіти щодо науково-методичного забезпечення організації науково-дослідницької діяльності учнів.

у 2019 р. Інститут і МАН провели 12 масових науково-практичних заходів, зокрема: дві міжнародні конференції; п'ять науково-практичних семінарів; семінар-практикум; круглий стіл; три всеукраїнських конкурси.

За науково-методичним напрямом співробітники Інституту розробили, апробували і впровадили в практику роботи МАН такі науковометодичні розробки:

- методику діагностики особистісних чинників розвитку інтелектуальної обдарованості старшокласників;

- методику запобігання деструктивній соціалізації обдарованих старшокласників в інтернет-середовищі, що забезпечує соціальнопедагогічну та психологічну реабілітацію учнів, які зазнали його негативного впливу;

- технологію підготовки обдарованої молоді до участі в міжнародних конференціях дослідницького спрямування, що передбачає системну підготовку юних дослідників до подання результатів наукової роботи на міжнародних конкурсах дослідницького напряму;

- методику реалізації STEM-підходу до навчання у процесі комплексних досліджень природних об'єктів рідного краю в рамках природничо-наукових експедицій МАН; 
- модель STEM-компетентностей, яка окреслює сучасні підходи до організації освітнього процесу на засадах дослідно-пошукової роботи;

- методичні засади планування, організації та реалізації STEM-проєктів;

- програму з розвитку дослідницьких компетентностей учнів-членів МАН;

- методику створення навчальних STEMпроєктів, яку відображено в методичних рекомендаціях «Упровадження STEM-освіти в умовах інтеграції формальної і неформальної освіти обдарованих учнів».

Позитивної оцінки заслуговує розроблене Інститутом спільно з МАН та $\mathrm{MOH}$ України науково-методичне забезпечення діяльності віртуальної STEM-лабораторії МАНЛаб (https:// stemua.science/), яка пропонує дистанційну й очну фахову методичну та технологічну допомогу в організації STEM-навчання учнівської молоді України і спеціалізується на дослідженнях у галузі природничих дисциплін: фізики, хімії, біології, географії, астрономії, екології, мінералогії. Освітнє середовище STEM-лабораторії містить навчальні програми, методичні матеріали, віртуальні лабораторії, які можуть бути корисними для учнів, студентів, учителів, вчених. Станом на 10 березня 2020 р. у віртуальному центрі розміщено понад 200 навчальних матеріалів і зареєстровано 150000 відвідувань за місяць.

Вагомим аспектом співробітництва Інституту і МАН $€$ міжнародна наукова співпраця. Упродовж 2019 р. проведено низку науково-практичних заходів міжнародного рівня, організовано зустрічі з провідними фахівцями в галузі обдарованості та наукової освіти. Зокрема, організовано прийом чотирьох іноземних делегацій:

- професора Кеслтонського коледжу (США), редактора Міжнародного журналу для обдарованих і талановитих (GTI) при Світовій раді з питань обдарованих і талановитих дітей (WCGTC) Тревора Дж. Теббса. За результатами зустрічі визначено подальші плани спільної діяльності зі створення онлайн-ресурсу для психологів навчальних закладів з метою діагностики обдарованих учнів. Окреслено можливості використання теоретичних доробок професора українськими вченими;

- директорки департаменту політики в галузі науки і розвитку наукової бази секретаріату UNESCO Пеггі Ефуа Оті-Боатенг і президента міжнародної організації «Філософія для дітей країн Азії та Океанії», співзасновника Корейської

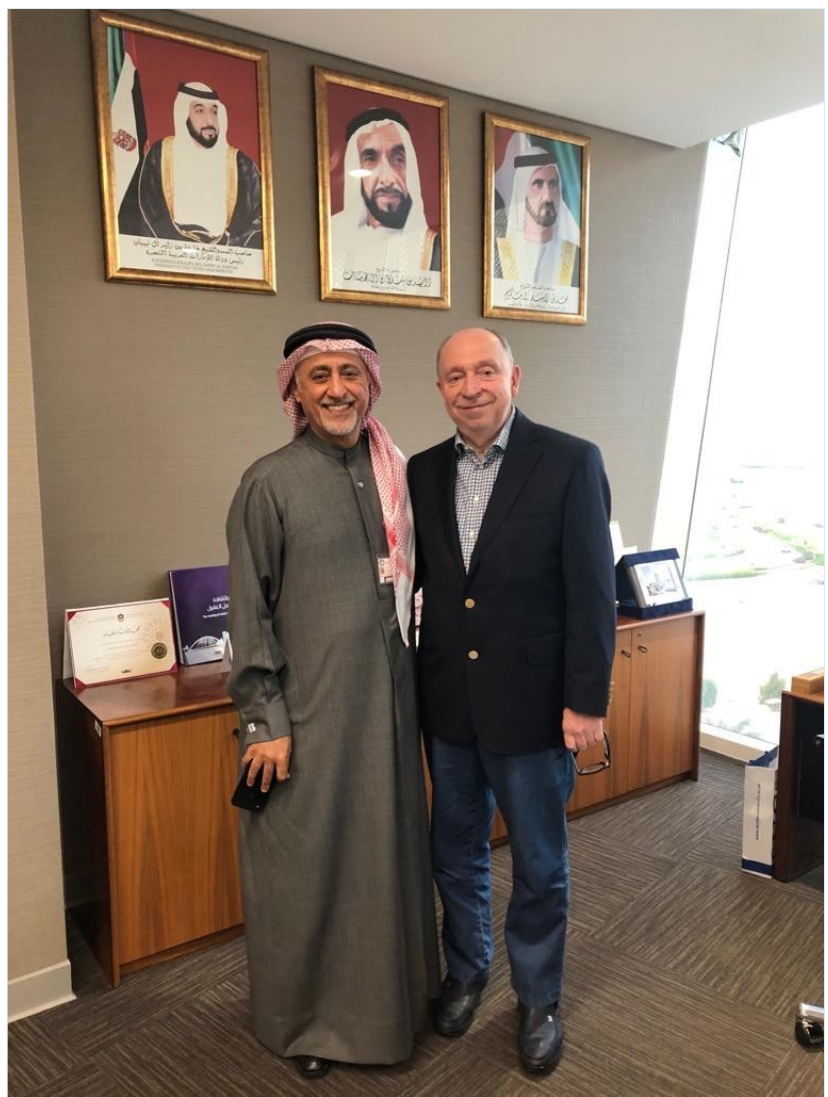

академії навчання філософії у школі Джінвана Парка. За результатами зустрічі домовлено про надання запрошеним гостям методичних матеріалів щодо запровадження напряму «Філософія для дітей» в Україні;

- генерального секретаря Європейської академії наук, мистецтв і літератури, професорки Ніколь Лемер Д'Агаджіо (Франція), яка запропонувала налагодити спільну роботу зі створення методик розвитку дітей дошкільного віку засобами мистецтва;

- делегації з освітнього центру «Educenter» Азербайджанської Республіки у кількості 12 осіб. Члени делегації виявили інтерес до методик проєктування розвитку обдарованості, розроблених Інститутом, а також обговорили шляхи майбутньої співпраці.

Загалом проведено п'ять міжнародних науково-практичних заходів.

Інститут і МАН виконують низку спільних проєктів, спрямованих на здійснення міжнародної конкурсної діяльності Національного центру «Мала академія наук України», що сприяють щорічному відбору та підготовці учнів-членів МАН до участі в міжнародних інтелектуальних змаганнях. 3-поміж них варто назвати Міжнародну конференцію юних дослідників ICYS, яка $\epsilon$ особливим видом індивідуальних змагань 3 
фізики, математики, інформатики та екології для учнів 14-18 років. Упродовж року проводиться національний етап конкурсного відбору учасників конференції, який передбачає: онлайнреєстрацію учасників; психолого-педагогічне тестування; віртуальні зустрічі з членами відбіркової комісії; навчання у дистанційній школі молодого вченого; очну підготовку до участі в міжнародних змаганнях. На основі цих заходів формується команда юних дослідників, які представляють результати власного наукового пошуку (в галузі теоретичної чи прикладної фізики, екології довкілля, екології життя, математики або інформатики) на міжнародному конкурсі юних дослідників. Здобутком цієї співпраці $\epsilon$ вагомі досягнення українських молодих дослідників на різних міжнародних конкурсах і олімпіадах. Зокрема, у 2019 р. команда України з восьми учасників на змаганнях у Малайзії виборола одну золоту, дві срібні і дві бронзові медалі.

Серед пріоритетних напрямів подальшої співпраці варто виділити такі:

- розробити критерії відбору учнівської молоді для її залучення до наукової та науковотехнічної діяльності і створити відповідний інструментарій, який дав би можливість для ефективного пошуку обдарованих учнів і залучення їх до дослідницької діяльності;

- створити програмні та методичні матеріали для підтримки наукової та науково-технічної діяльності обдарованих учнів через систему спеціалізованих, загальноосвітніх і позашкільних закладів, зокрема Малої академії наук України, як цілісної системи розвитку інтелектуально обдарованих учнів в Україні на засадах поєднання формальної і неформальної освіти;

- налагодити співпрацю Інституту та інших наукових установ НАПН України з Малою академією наук України та урізноманітнити ії форми, оскільки в структурі академії $\epsilon$ підрозділи, що досліджують проблеми обдарованості і могли б використати потенціал МАН як експериментальний майданчик для упровадження своїх розробок;

- забезпечити ширше представлення і популяризацію результатів спільної діяльності Інституту обдарованої дитини та Малої академії наук України в засобах масової інформації, інтернет-середовищі, соціальних мережах.

\title{
ON COOPERATION BETWEEN THE INSTITUTE OF THE GIFTED CHILD OF THE NATIONAL ACADEMY OF EDUCATIONAL SCIENCES OF UKRAINE AND THE JUNIOR ACADEMY OF SCIENCES OF UKRAINE ON THE IMPLEMENTATION OF SPECIALIZED EDUCATION OF SCIENTIFIC DIRECTION Scientific report at the meeting of the Presidium of the National Academy of Educational Sciences of Ukraine, March 19, 2020
}

\section{Stanislav Dovgyi}

DSc in Physics and Mathematics, Professor, Full Member (Academician) of NAS of Ukraine and NAES of Ukraine, President, National Center "Junior Academy of Sciences of Ukraine", Kyiv, Ukraine Maksym Halchenko

PhD in Philosophy, Director, Institute of the Gifted Child of the National Academy of Educational Sciences of Ukraine, Kyiv, Ukraine

\begin{abstract}
The report outlines the main areas of cooperation between the Institute of the Gifted Child of the National Academy of Educational Sciences of Ukraine and the Junior Academy of Sciences of Ukraine on the implementation of specialized education of scientific direction. It is emphasized that the Law of Ukraine "On Education" creates a legitimate basis for the reorientation of the educational process from the mechanical learning of the formal set of knowledge to the development of research competencies as universal personal cognitive and creative tools. The central thesis of the report is that the effective implementation of the provisions of the Law of Ukraine on the introduction of specialized education of scientific direction into broad educational practice is not possible without the synergy of the main stakeholders in the educational process, who are concerned with this issue. Namely: the Institute of the Gifted Child of NAES of Ukraine and the Junior Academy of Sciences of Ukraine.

Today, the synergy of efforts of the Institute of the Gifted Child of NAES of Ukraine and Junior Academy of Sciences of Ukraine is traced at several levels: normative, scientific-organizational and scientific-methodological support of education of scientific direction and at the level of international scientific cooperation.

In spite of significant achievements in the field of introduction of specialized education of scientific direction in terms of implementation of the concept of the New Ukrainian School, a number of necessary scientific steps in the near future that will promote both the popularization of science education in the domestic territories and increase the efficiency of the educational system of Ukraine itself is emphasized.

Keywords: specialized education of scientific direction; giftedness; research competences; Institute of the Gifted Child of NAES of Ukraine; Junior Academy of Sciences of Ukraine.
\end{abstract}

Дата публікації: 23 березня 2020 р. 